\title{
Impact of Flexible Working Hours on Work-Life Balance
}

\author{
Sussanna Shagvaliyeva, Rashad Yazdanifard \\ Centre of Post Graduates Studies, Limkokwing University of Creative Technology, Cyberjaya, Malaysia. \\ Email:shagvaliyeva@gmail.com, rashadyazdanifard@yahoo.com
}

Received December $10^{\text {th }}, 2013$; revised January $1^{\text {st }}, 2014$; accepted January $6^{\text {th }}, 2014$

Copyright (C) 2014 Sussanna Shagvaliyeva, Rashad Yazdanifard. This is an open access article distributed under the Creative Commons Attribution License, which permits unrestricted use, distribution, and reproduction in any medium, provided the original work is properly cited. In accordance of the Creative Commons Attribution License all Copyrights (C) 2014 are reserved for SCIRP and the owner of the intellectual property Sussanna Shagvaliyeva, Rashad Yazdanifard. All Copyright (C) 2014 are guarded by law and by SCIRP as a guardian.

\begin{abstract}
Nowadays, flexible working hours are becoming important to the workplaces. A lot of organizations offer flexible working hours to employees due to the benefits that flexibility gives to both employee and employer. Greater employee productivity and higher organization profitability are the most common benefits. Also, flexible working hours promote and facilitate work-life balance. Reduced stress and increased employee wellbeing are outcomes of the work-life balance. In this paper, the relationship between flexible working hours and work-life balance is investigated.
\end{abstract}

\section{KEYWORDS}

Flexible Working Hours; Benefits; Work-Life Balance; Stress; Wellbeing

\section{Introduction}

Flexible working hours have recently gained a lot of attention from organizations and scholars as family-friendly policy. Nowadays, organizations are trying to incorporate a culture of trust by offering employees flexibility in the workplace [1]. In addition, some researchers argue that flexible working practices facilitate work-life balance, and with shifting family patterns such practices are beneficial for both women and men [2-4]. In this paper, relationship between flexible working hours and worklife balance is examined. This paper investigates whether flexible working hours support and enhance work-life balance or conversely create difficulties in balancing between work and life roles.

Firstly, some previous findings on flexible working hours are examined. With the use of existing evidence, flexible working hours are considered from employee and employer sides in order to show that flexibility in the workplace beneficial is not only for employee, but for employer as well. Secondly, existing literature on worklife balance is scanned. Stress and employee wellbeing are discussed as they are two key outcomes of work-life balance, one is negative and the other one is positive re- spectively. The literature lacks the evidence of flexible working hours impacting on work-life balance; however, two concepts are frequently used together in the studies. The paper proceeds with a brief discussion on a chosen topic. And finally, conclusion is provided to summarize the ideas of the paper.

\section{Flexible Working Hours}

Work flexibility implies not only variation in time and place of the job, but also sharing of the job, career breaks (maternity/paternity leaves), part-time and term-time working [5]. In the other study on flexible work arrangement (FWA), researchers discussed three broad categories of FWA-flexi-time (flexibility in scheduling), telehomeworking (flexibility in location), and part-time (flexibility in length of the work) [6]. While each of the arrangement could be used individually, they are frequently combined to compliment each other [7]. It should be noted that work flexibility offers convenience in planning, not reducing the working time. Thus, flexibility in work might be summarized as the ability of employee to control his/her working time duration as well as location of work (remotely from office), this ability in scheduling 
work suppose to be offered by employer [8].

\subsection{Benefits for Employers}

Employers have introduced flexible working packages (part of work-life policy) in order to attract, recruit, and retain highly qualified staff to their organizations [9]. With the ability to schedule the work himself/herself, employee feels that employer cares about wellbeing and non-working life of employee [10]. That leads to increased satisfaction with the job and employer, resulting in higher work commitment [11]. According to some other previous findings, flexible working result in employee loyalty and engagement, increased organizational commitment, and higher job satisfaction, also flexible working packages help to recruit and retain talented employees for the organization [12]. Furthermore, increased productivity, reduced employee turnover and absenteeism have been identified as advantages of flexible working for the employers [13]. Thus, flexible working practices are beneficial for employers, hence flexibility was embedded to the work in order to give employees an option to choose at what time, how much time, and from which place to work.

\subsection{Benefits for Employees}

Despite apparent advantages of flexible working practices (employee personal control over work scheduling), some employees, mostly men, think that such practices result in lower income and higher employment insecurity [14]. According to the same findings, men see flexible working practices as a way to develop their organizational commitment, while women associate flexibility with the work-life balance improvement. The evidence suggests that flexible working practices fit women more then men and are more likely to be employed by women due to the ideology beliefs of motherhood [15]. The findings from previous research also assert that women request and access the flexible working hours more frequently then men [16]. However, due to the changing family patterns and gender norms, as well as rise of women workforce, flexible employment is slowly started utilizing by men these days [17]. Flexible working practices help to fulfil work-life responsibilities and might result in work-life balance. The literature suggests that there is a positive relationship between flexible working practices and health issues-employees' better mental health and stress reduction [18].

\section{Work-Life Balance}

Work-life balance concept recently gained attention due to its relevance and importance to all employees, despite of their relationship status, family size, and number of children. Some researchers believe that lack of balance is an effect of conflict between work and life responsibilities [19]. In their study on the support for the work-life balance, researchers found that emotional and instrumental support for employee during the work has a positive relationship with the work-life balance satisfaction [20]. The positive relationship has been found between worklife balance and work performance [21]. Thus, successful accomplishment of life responsibilities (family and parental roles) results in better work performance. While finding a balance in life and work responsibilities increase general life satisfaction [22].

\subsection{Stress and Work-Life Balance}

Each person defines stress in a different way. For some stress occurs from working overtime, from pressure to meet deadlines, or from fear of failure. In general, stress occurs when person has no control over when, where, and how he/she does the work [23]. High level of stress might result in mental and physical health problems, such as headaches, depression, heart attack, and cancer; stress is also an antecedent of unhappy and disharmonious relationships that cause work-life conflict [24]. The evidence suggests that those employees who have work-life balance difficulties experience higher stress then those who found balance between work and life responsibilities [25].

\subsection{Wellbeing and Work-Life Balance}

The definition of wellbeing is associated with health and wellness [26]. It is employer's responsibility to create working environment (workplace wellness culture) that promote employee wellbeing [27]. Furthermore, authors suggest that physiological wellbeing leads to mental wellbeing, and both are helping to achieve work-life balance. The other previous findings suggest that employee wellbeing directly influence productivity and performance; as well as organizational commitment, job satisfaction, and work-life balance are outcomes of employee wellbeing [28-30].

\section{Flexible Working Hours and Work-Life Balance}

Flexible working hours have been introduced as a benefit for parent/caring employees in order to help them fulfilling work and life responsibilities and achieving worklife balance [31]. In the recent work-life balance survey, researchers found that employees believe that flexible working practices improve workplace morale, which might positively influence work-life balance; in addition employees believe that employer is able to help them balance their work and life roles [32]. As an example, flexible working hours is one of the best activities to increase employee wellbeing, as it helps employee to deal 
with responsibilities outside the work [33].

\section{Discussion}

Flexible working practices are beneficial for both employee and employer. Hence, in the first place flexibility was introduced to the workplace in order to help employees with kids or employees who care after siblings to manage their time between work and life. As flexibility gives employee the ability to control when, where, and how much time do they work, flexibility definitely contributes to improvement in allocation of work and life responsibilities. Thus, employee might end up fulfilling his/her working as well as well non-working roles easily. Finally, successful achievement of inside the work and outside the work responsibilities leads to finding worklife balance, which increase overall life satisfaction. To summarize, it might be said that use of flexible working practices positively influence on work-life balance and overall life satisfaction of the employee.

Looking from employer point of view, flexibility in the workplace also brought some important benefits. Higher satisfaction with the work and employer, better employee performance, greater organizational commitment, and lower employee turnover and absenteeism are all outcomes of flexible working practices that at the end lead to increasing company's productivity and profitability.

The stress on the work impacts on employee's personal outside the work life, which creates difficulties in finding work-life balance. Stress causes some serious mental and physical problems that negatively influence on employee's productivity and wellbeing. Thus, it might be said that on the work stress decreases employee's work-life balance, while wellbeing contributes to higher level of work-life balance. It is the responsibility of employer to create the wellness workplace (stress-free and trust-based environment) for employees in order to increase their productivity.

Previously, flexible working hours have been highly requested and used by women due to their family roles. However, flexible working hours are offered to men as well. Nowadays, both women and men due to the new family patterns use flexible working practices, where both parents have equal family roles and dual family income. Thus, it is important for both of them to successfully fulfil work and life responsibilities and achieve work-life balance.

\section{Conclusions}

This paper examined flexible working hours from its positive point of view. The investigation showed that introduction of flexible working hours brought some benefits for both employee and employer. Also, flexibility in the workplace gives employees time to perform outside of the work roles and it helps balance employees' work and life.

Trust between employer and employee is an important issue when it comes to flexible working hours. If not monitored by manager, flexible working hours might create some difficulties in the workplace. Further study on flexible working hours need to be taken to understand the drawbacks of such practices. Only after investigating flexible working practices from both positive and negative sides, organizations might consider applying flexibility to the workplace.

\section{REFERENCES}

[1] Expert Group Meeting, "Work-Life Policy, Practice and Potential," Presentation to the Management Committee Office of the Focal Women in the United Nations, Office of the Focal Point for Women, United Nations, 2010.

[2] P. Thomson, "The Business Benefits of Flexible Working,” Strategic HR Review, Vol. 7, No. 2, 2008, pp. 17-22. http://dx.doi.org/10.1108/14754390810853129

[3] E. Pruyne, M. Powell and J. Parsons, "Developing a Strategy for Employee Wellbeing: A Framework for Planning and Action,” Ashridge Business School, Nuffield Health, 2012.

[4] D. Hofacker and S. Konig, "Flexibility and Work-Life Conflict in Times of Crisis: A Gender Perspective," International Journal of Sociology and Social Policy, Vol. 33, No. 9-10, 2013, pp. 613-635. http://dx.doi.org/10.1108/IJSSP-04-2013-0042

[5] D. Torrington, S. Taylor, L. Hall and C. Atkinson, "Human Resource Management,” Financial Times Prentice Hall, New Jersey, 2011.

[6] D. Possenried and J. Plantenga, "Access to Flexible Work Arrangements, Working-Time Fit and Job Satisfaction,” Tjalling C. Koopmans Research Institute, Utrecht, 2011.

[7] H. Chung, "Flexibility for Whom? Working Time Flexibility Practices of European Companies,” Tilburg University, Tilburg, 2009.

[8] C. Atkinson and L. Hall, "Flexible working and hapiness in the NHS,” Employee Relations, Vol. 33, No. 2, 2011, pp. 88-105.

[9] R. Croucher and C. Kelliher, "The Right to Requiest Flexible Working in Britain: The Law and Organizational Realities," European Journal of Comparative Law and Industrial Relations, Vol. 21, No. 3, 2005, pp. 503-529.

[10] W. J. Casper and C. M. Harris, "Work Life Benefits and Organizational Attachment: Self-Interest Utility and Signaling Theory Models," Journal of Vacational Behavior, Vol. 72, No. 1, 2008, pp. 95-109. http://dx.doi.org/10.1016/j.jvb.2007.10.015

[11] C. Kelliher and D. Anderson, "Doing More with Less? Flexible Working Practices and Intesification of Work," Human Relations, Vol. 63, No. 1, 2010, pp. 83-106. http://dx.doi.org/10.1177/0018726709349199

[12] D. Anderson and C. Kelliher, "Flexible Working and 
Engagement: The Importance of Choice," Strategic HR Review, Vol. 8, No. 2, 2009, pp. 13-18. http://dx.doi.org/10.1108/14754390910937530

[13] Anon, "Flexible Working as Human Resource Strategy: Benefits to the Organization and its Personnel," Strategic Direction, Vol. 24, No. 8, 2008, pp. 9-11. http://dx.doi.org/10.1108/02580540810884584

[14] D. Hofacker and S. Konig, "Flexibility and Work-Life Conflict in Times of Crisis: A Gender Perspective," International Journal of Sociology and Social Policy, Vol. 33, No. 9-10, 2013, pp. 613-635. http://dx.doi.org/10.1108/IJSSP-04-2013-0042

[15] S. Lewis and A. L. Humbert, "Work-Life Balance, Flexible Working Policies and the Gendered Organization," Equality, Diversity and Inclusion: An International Journal, Vol. 29, No. 3, 2010, pp. 239-254. http://dx.doi.org/10.1108/02610151011028840

[16] N. Skinner and B. Pocock, "Flexibility and Work-lIfe Interference," Journal of Industrial Relations, Vol. 53, No. 1, 2011, pp. 65-82. http://dx.doi.org/10.1177/0022185610390297

[17] D. Hofacker and S. Konig, "Flexibility and Work-Life Conflict in Times of Crisis: A Gender Perspective," International Journal of Sociology and Social Policy, Vol. 33, No. 9-10, 2013, pp. 613-635. http://dx.doi.org/10.1108/IJSSP-04-2013-0042

[18] M. Shapiro, C. Ingols, R. O’Neill and S. Blake-Beard, "Making Sense of Women as Career Self-Agents: Implications for Human Resource Development," Human Resource Development Quarterly, Vol. 20, No. 4, 2009, pp. 477-501. http://dx.doi.org/10.1002/hrdq.20030

[19] H. Lingard and V. Francis, "Managing Work-Life Balance in Construction,” Spon Press, New York, 2009.

[20] A.-K. Abendroth and L. den Dulk, "Support for the Work-Life Balance in Europe: The Impact of State, Workplace, and Family Support on Work-Life Balance Satisfaction,” Work, Employment, and Society, Vol. 25, No. 2, 2011, pp. 234-256. http://dx.doi.org/10.1177/0950017011398892

[21] S. K. Lyness and K. M. Judiesch, "Can a Manager have a Life and a Career? International and Multisource Perspective on Work-Life Balance and Career Advancement Potential,” Journal of Applied Psychology, Vol. 93, No. 4, 2008, pp. 789-805. http://dx.doi.org/10.1037/0021-9010.93.4.789
[22] M. Pina e Cunha and A. Rego, "Do the Opportunities fo Learning and Personal Development Lead to Happiness? It depends on Work-Family Conciliation,” Journal of Occupational Health Psychology, Vol. 14, No. 3, 2009, pp. 334-348. http://dx.doi.org/10.1037/a0014248

[23] K. Lockett, "Work/Life Balance for Dummies," John Wiley \& Sons, Hoboken, 2012.

[24] T. Looker, "Manage Your Stress for a Happier Life," Copyright Licensing Agency Limited, London, 2011.

[25] G. Lowe, "Under Pressure: Implication of Work-Life Balance and Job Stress," Wilson Banwell PROACT Human Solutions, Kingston, 2006.

[26] E. Pruyne, M. Powell and J. Parsons, "Developing a Strategy for Employee Wellbeing: A Framework for Planning and Action,” Ashridge Business School, Nuffield Health, 2012.

[27] E. E. Kossek, T. Kalliath and P. Kalliath, "Achieving Employee Wellbeing in a Changing Work Environment," International Journal of Manpower, Vol. 33, No. 7, 2012, pp. 738-753. http://dx.doi.org/10.1108/01437721211268294

[28] R. N. Baptiste, "Tightening the Link between Employee Wellbeing at Work and Performance,” Management Desicion, Vol. 46, No. 2, 2008, pp. 284-308.

[29] K. A. Jain, I. S. Giga and L. C. Cooper, "Employee Wellbeing, Control and Organizational Commitment," Leadership \& Organization Development Journal, Vol. 30, No. 3, 2009, pp. 256-273. http://dx.doi.org/10.1108/01437730910949535

[30] E. E. Kossek, T. Kalliath and P. Kalliath, "Achieving Employee Wellbeing in a Changing Work Environment," International Journal of Manpower, Vol. 33, No. 7, 2012, pp. 738-753. http://dx.doi.org/10.1108/01437721211268294

[31] P. Thomson, "The Business Benefits of Flexible Working,” Strategic HR Review, Vol. 7, No. 2, 2008, pp. 17-22. http://dx.doi.org/10.1108/14754390810853129

[32] S. Tipping, J. Chanfreau, J. Perry and C. Tait, "The Fourth Work-Life Balance Employee Survey," Department for Business, Innovation and Skills (BIS), London, 2012.

[33] E. Pruyne, M. Powell and J. Parsons, "Developing a Strategy for Employee Wellbeing: A Framework for Planning and Action," Ashridge Business School, Nuffield Health, 2012. 